J. Pcrinat. Med.

1 (1973) 245

\title{
Analyses of tractive forces during the application of vacuum extraction
}

\author{
Erich Saling, Michael Hartung \\ Unit of Perinatal Medicine The Free University of Berlin, \\ Dept. of Obstetrics and Gynecology, Berlin (West)-Neukölln,
}

Received July 9, 1973. Accepted August 22, 1973.

Vacuum extraction dates back to the 18th century [1]. MALMSTRÖM first introduced a fully practicable vacuum extractor as an operative method of delivery about 20 years ago [2]. Vacuum extraction has since found increasing application and is considered in many countries to be as useful as forceps.

Numerous articles have been published concerning technique and clinical application of vacuum extraction. To date, howrever, there has been no direct research, as far as we know, about the extent of the effective tractive forces and the length of application during the extraction. Because of this lack criteria based upon subjective judgments were used to characterize a vacuum extraction. Such criteria are insufficient for objective analysis of tractive forces.

We have therefore developed a device for the recording of tractive forces in vacuum extractions as presented in the last issue of this Journal [4]. In connection with that article we are now reporting our first results.

\section{Case material and methods}

During the period from April 1972 to February 1973 we investigated 74 clinically indicated vacuum extractions with the above mentioned apparatus. Fig. 1 shows an example of a record. From all 74 records we have evaluated the following parameters:

a) length of the whole operative measure

b) total duration of the applied forces

c) magnitude of the maximum tractive force d) number of individual tractions

e) force-time-integral (FTI)

For the measurement of the force-time-integral (FTI) the record was evaluated planimetrically by means of a transparent overlay. The planimetrically evaluated result represents the time integral of force $=\int \mathrm{Fdt}=\mathrm{FTI}$ (force-timeintegral). $1 \mathrm{~mm}^{2}$ on the recording paper corresponds to $3.75 \mathrm{kpsec}(=36.78 \mathrm{kgm} / \mathrm{sec}$ ) at a recording speed of $2 \mathrm{~cm}$ per minute.

\section{Results}

Tab. I presents a survey of the indications for operative delivery by vacuum extractor in our material. In more than $80 \%$ of the cases vacuum extraction was indicated by delay of second stage or acidity-increase determined by fetal blood sampling.

Tab. I. Indications for vacuum extraction.

\begin{tabular}{|c|c|}
\hline Delay of second stage & $\mathrm{n}=48$ \\
\hline Acidity increase in the fetus & $\mathrm{n}=15$ \\
\hline Acute bradycardia with silent oscillations & $\mathrm{n}=5$ \\
\hline $\begin{array}{l}\text { Continual tachycardia of more than } 3 \mathrm{~h} \\
\text { duration }\end{array}$ & $\mathrm{n}=4$ \\
\hline Deep transverse arrest & $\mathrm{n}=1$ \\
\hline \multirow[t]{2}{*}{ Maternal predisposition to seizures } & $\mathrm{n}=1$ \\
\hline & $\mathrm{tal}=74$ \\
\hline
\end{tabular}

All were cases of vertex presentation in which the major portion of vacuum extractions was performed with the level of the fetal head at 

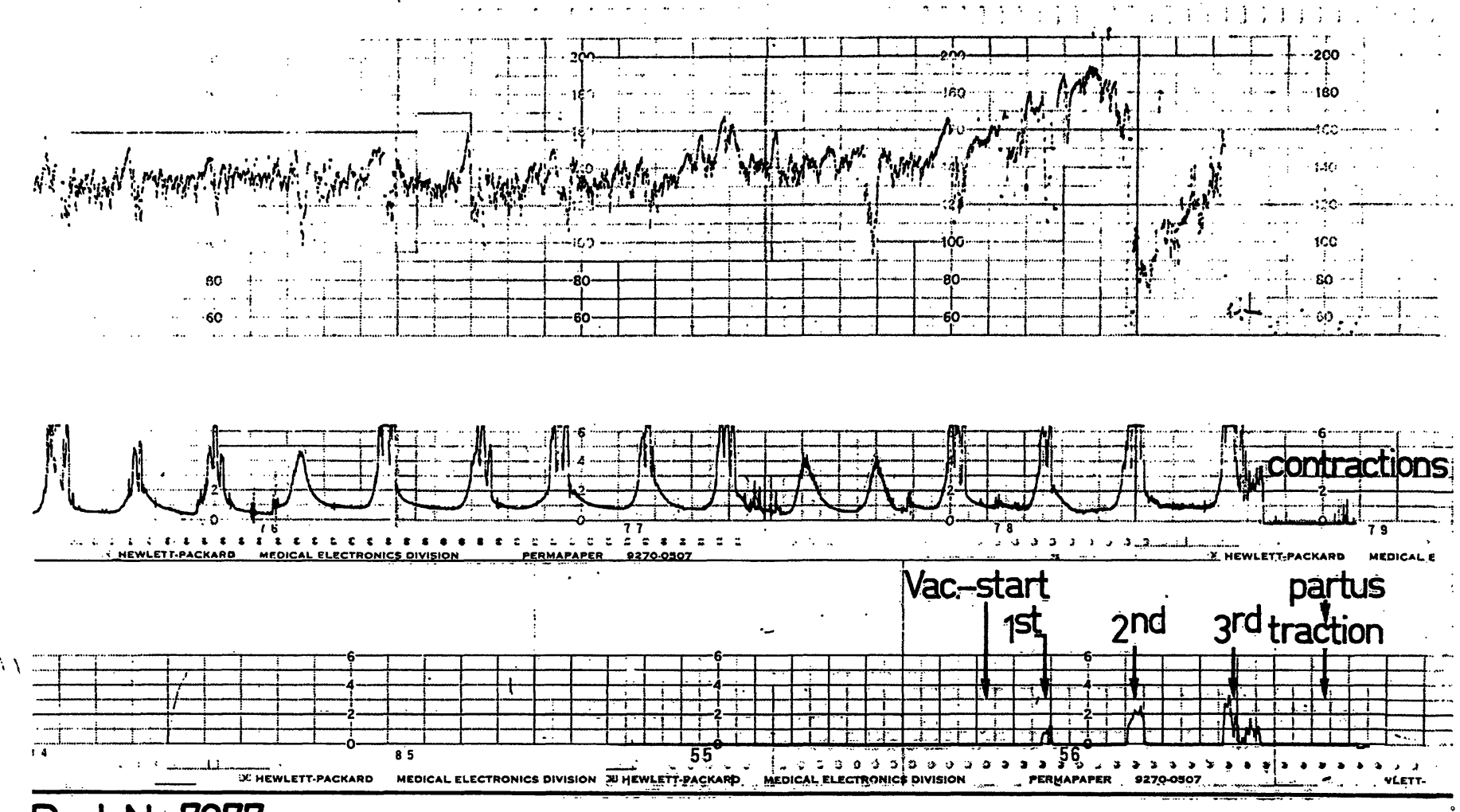

Prot. No 7077

Vacuum extraction, cord around the neck $1 x$

U.A.pHact $=7.31 /$ U.A.pHqu $40=7.30$

Score $=10 / 4, A=\overline{\bar{V}}, C=\overline{\underline{V}}$

Fig. 1. Record of fetal heart rate (upper section), uterine contractions (middle section) and applied tractive forces during vacuum extraction (bottom section). One division is $5 \mathrm{kp}$, paper-speed $1 \mathrm{~cm} / \mathrm{min}$.

mid-pelvic-plane $(\mathrm{n}=44)$ and pelvic floor $(\mathrm{n}=22)$. In 6 cases the baby was extracted from the pelvic outlet and in only 2 cases from the pelvic inlet. We used exclusively the largest suction cup with a diameter of $6 \mathrm{~cm}$.

As expected the duration of the vacuum extraction, the number of individual tractions, the magnitude of the maximum tractive force correlate with the level of the fetal head (see Tab. II). The higher the position of the fetal head at the beginning of the vacuum extraction the longer the duration of the operative measure and the greater the number of individual tractions and the magnitude of the maximum tractive force.

In 22 cases the maximum tractive force was $\geqq 20 \mathrm{kp}$. In 10 of these 22 cases the suction cup came off. There was no coming off of the suction cup with a maximum tractive force of less than $20 \mathrm{kp}$. It is possible for the suction cup to come of as well in cases of less tractive force. In such cases, however, the threat of coming off can be recognized in time by the sound of entering air, so that the tractive force can be interrupted early enough. In half the cases of coming off we found depressed newborns $(n=5)$. The total number of depressed newborns was 11 .

The force-time-integrals show similar results. The force-time-integral increases corresponding to the level of the fetal head. Tractions with FTI-values of less than $375 \mathrm{kpsec}$ where required chiefly for extractions from the pelvic floor and the pelvic outlet. Tractions of more than $1500 \mathrm{kpsec}$ were necessary. only for extractions from higher pelvic levels (Fig. 2). 
Tab. II. Number of tractions, maximum tractive force, length of the whole operative measure and total duration of the applied tractions.

\begin{tabular}{|c|c|c|c|c|}
\hline & $\begin{array}{c}\text { Number of } \\
\text { tractions } \\
\text { (mean) }\end{array}$ & $\begin{array}{c}\text { Maximum } \\
\text { tractive force } \\
{[\mathrm{kp}]}\end{array}$ & $\begin{array}{l}\text { Length of } \\
\text { whole operative } \\
\text { measure } \\
\text { [min] } \\
\text { (mean) }\end{array}$ & $\begin{array}{l}\text { Total duration } \\
\text { of applied } \\
\text { tractions } \\
\text { [min] } \\
\text { (mean) }\end{array}$ \\
\hline Pelvic inlet & 2.50 & $19.50 \mathrm{kp}$ & $3 \mathrm{~min}$ & $2 \mathrm{~min}, 37 \mathrm{sec}$ \\
\hline Midpelvic plane & 2.52 & $17.84 \mathrm{kp}$ & $2 \mathrm{~min}, 34 \mathrm{sec}$ & $2 \mathrm{~min}, 10 \mathrm{sec}$ \\
\hline Pelvic floor & 1.95 & $14.31 \mathrm{kp}$ & $1 \mathrm{~min}, 19 \mathrm{sec}$ & $1 \mathrm{~min}, 17 \mathrm{sec}$ \\
\hline Pelvic outlet & 1.66 & $10.33 \mathrm{kp}$ & $1 \mathrm{~min}, 10 \mathrm{sec}$ & $1 \mathrm{~min}, 2 \mathrm{sec}$ \\
\hline Maximum & 8 & $28 \mathrm{kp}$ & $12 \mathrm{~min}, 30 \mathrm{sec}$ & $8 \mathrm{~min}, 40 \mathrm{sec}$ \\
\hline Minimum & 1 & $6 \mathrm{kp}$ & $10 \mathrm{sec}$ & $10 \mathrm{sec}$ \\
\hline
\end{tabular}

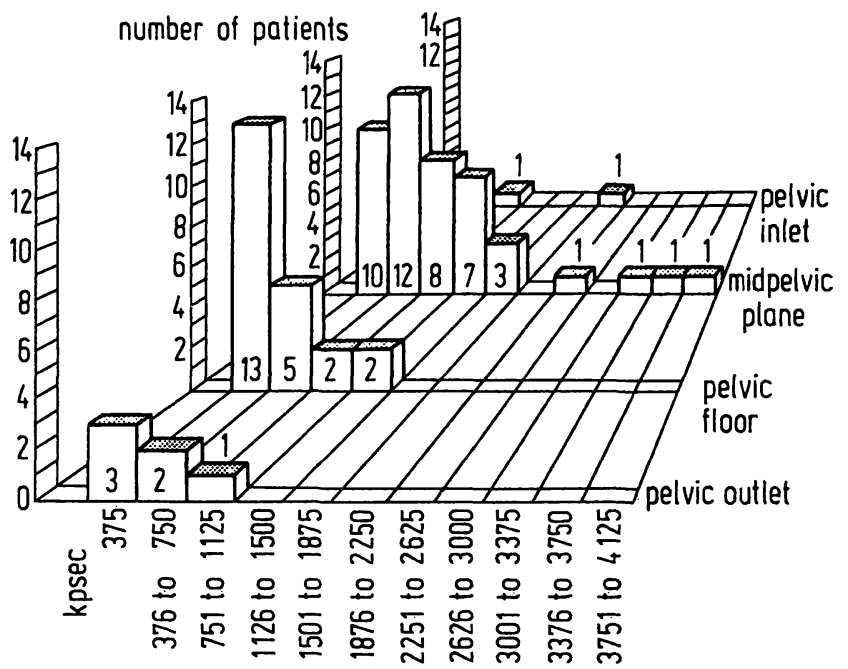

Fig. 2. Force-Time-Integrals of vacuum extractions from the various pelvic planes. Number of cases is placed within or above the columns (kpsec $=$ kilopondsecond).

Fig. 3 represents most clearly the relationship between the extractions from the pelvic inlet and mid-pelvic plane as well as from the pelvic floor and the pelvic outlet expressed as 2 pairs on the graph. As the FTI increases, the relative portions of vacuum extractions from higher levels correspond almost inversely proportionally to those from lower levels. It follows that the level of the fetal head is the first significant parameter for the magnitude of the FTI.

In examining the influence of fetal size upon the forces of extraction we compared the FTI of infant groups with different birth weights at

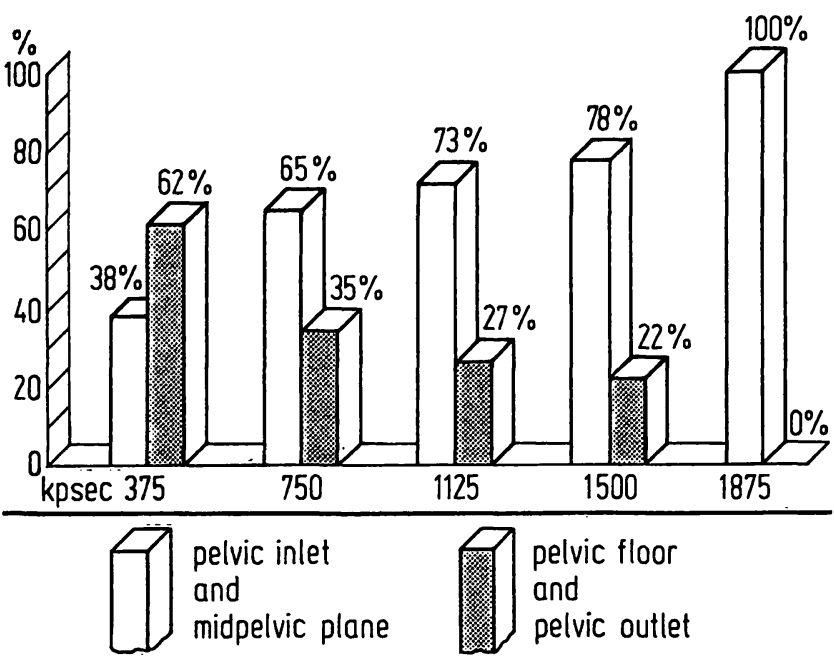

Fig. 3. Relative portions of vacuum extractions from pelvic inlet and midpelvic plane as well as from pelvic floor and pelvic outlet correlated with increasing Force-TimeIntegral.

same level of the fetal head. Although this subdivision naturally results in a smaller number of cases, the evaluation shows a clear correlation between FTI and neonatal birthweight. As compared with the extraction of a baby weighing $2900 \mathrm{~g}$ from the mid-pelvic plane we found the FTI doubled at a birthweight of $3700 \mathrm{~g}$ (s. Tab. III).

Therefore birthweight is the second important parameter for the magnitude of the FTI during vacuum extraction. 
Tab. III. Force-Time Integrals as a function of birthweight.

\begin{tabular}{llc}
\hline $\begin{array}{c}\text { Level of the } \\
\text { fetal head }\end{array}$ & $\begin{array}{c}\text { Birthweight } \\
{[\mathrm{g}]}\end{array}$ & $\begin{array}{c}\text { Mean FTI } \\
{[\mathrm{kpsec}]}\end{array}$ \\
\hline Midpelvic plane & $2500-2900 \mathrm{~g}$ & $83 \mathrm{kpsec}$ \\
& $2901-3700 \mathrm{~g}$ & $130 \mathrm{kpsec}$ \\
& $3701 \mathrm{~g}$ and more & $178 \mathrm{kpsec}$ \\
\hline Pelvic floor & $2500-2900 \mathrm{~g}$ & $43 \mathrm{kpsec}$ \\
& $2901 \mathrm{~g}$ and more & $79 \mathrm{kpsec}$ \\
\hline
\end{tabular}

$11(14 \%)$ of the 74 newborns delivered by vacuum extraction were born in a state of depression ( 2 cases $C$ I, 5 C II, 4 C III). In 5 of these 11 cases the suction cup came off (see above). The classifications of the clinical state are given in Fig. 4. We published a report of this classification system two years ago [3].

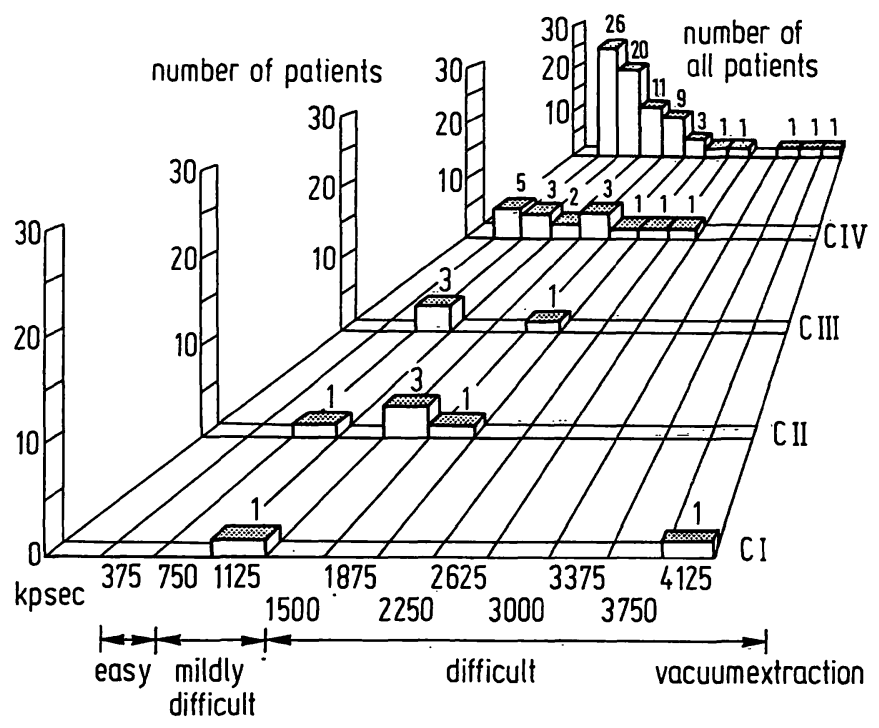

Fig. 4. Distribution-curve of all Force-Time-Integrals together with the corresponding number of newborns in a state of depression. Number of cases is placed within or above the columns. Correspondence of the scoring systems:

$\begin{array}{cc}\text { our system } & \text { APGAR } \\ \text { C IV } & 7-8 \\ \text { C III } & 5-6 \\ \text { C II } & 3-4 \\ \text { C I } & 0-2\end{array}$

It follows from Fig. 4 that the risk of neonatal depression grows with increasing FTI. We have therefore, for the time being arbitrarily, divided the degree of severity of a vacuum extraction into 3 groups:
1. Easy vacuum extraction up to $375 \mathrm{kpsec}$

2. Mildly difficult váduum extraction 376 to $1125 \mathrm{kpsec}$

3. Difficult vacuum extraction 1126 and more kpsec.

In the first group there are no cases of depressed newborns, in the second $5(16 \%)$ and in the third $6(33 \%)$. The depression of the newborn might be a result of the vacuum extraction or could be caused by other factors; this question remains to be resolved. To settle this problem we are applying the measurement of the $\mathrm{pH}$ value in the blood of the umbilical artery immediately post partum, part of our clinical routine for the past several years. The $\mathrm{pH}$-values of two of these 11 newborns were normal $\mathrm{pH} \geqq 7.25$ ). In two cases there was an increase in acidity ( $\mathrm{pH} 7.24-7.20$ ), in 6 newborns a slight acidosis was found ( $\mathrm{pH} 7.19-7.15)$ and 1 newborn had an advanced acidosis ( $\mathrm{pH}$ 7.02).

This enables us to exclude fetal hypoxia as $a^{3}$ cause of depression in at least four cases, so that we have to consider a relation between the vacuum extraction and the depressed state of the newborn.

\section{Discussion of the findings}

The results correspond with the common expectations of experienced clinicians. The advantage of our newly developed measuring device, however, is the possibility it presents to register accurately and record objectively for the first time the magnitude and duration of tractive forces as routine procedure.

We judge this to be an important step toward a complete collection of data concerning the birth. The clinical assessment of a vacuum extraction, especially its effects upon the child, can now be based upon measurable values; subjective miscalculations can be eliminated.

It would be premature to make far reaching clinical conclusions as a result of these findings. This problem can be first solved after further prospective research in connection with catamnestic inquiries. A great number of questions still remain open: e. g. incidence of traumàtic lesions, effects of the applied tractions upon 
the fetal heart rate, incidence of severe depression in vacuum extractions with a great FTI.

Our interest in this first analysis was centered upon researching force-time-relationships according to different parameters such as the level of the fetal head and birthweight.

Our findings to date lead to the following conclusions:

\section{Summary}

74 clinically indicated vacuum extractions were observed using our newly developed device for the measurement of tractive forces during vaccum extractions [4], (Fig. 1). The following parameters were evaluated:

length of the whole operative measure total duration of the applied tractions magnitude of the maximum tractive force number of individual tractions force-time-integral (FTI).

For extractions from the various pelvic planes the following mean values were found (pelvic inlet $=\mathrm{PI} / \mathrm{mid}$-pelvic plane $=\mathrm{MP} /$ pelvic floor $=\mathrm{PF} /$ pelvic outlet $=\mathrm{PO}):$

Number of tractions: PI:2.5; MP: 2.52; PF: 1.95; PO: 1.66 .

Maximum tractive force: PI: $19.50 \mathrm{kp}$; $\mathrm{MP}: 17.84 \mathrm{kp}$; PF: $14.31 \mathrm{kp}$; PO: $10.33 \mathrm{kp}$.

Length of the operative measure: $\mathrm{PI}: 3 \mathrm{~min}$; $\mathrm{MP}$ : $2 \mathrm{~min}, 34 \mathrm{sec}$; PF: $1 \mathrm{~min}, 19 \mathrm{sec}$; PO: $1 \mathrm{~min}, 10 \mathrm{sec}$.

Total duration of the applied tractions: PI: $2 \mathrm{~min}$, $37 \mathrm{sec}$; MP: $2 \mathrm{~min}, 10 \mathrm{sec}$; PF: $1 \mathrm{~min}, 17 \mathrm{sec}$; PO: $1 \mathrm{~min}$, $2 \mathrm{sec}$.

All cases investigated were vertex presentations. 44 newborns were delivered from the midpelvic plane, 22 from the pelvic floor, 6 from the pelvic outlet, and 2 from pelvic inlet.

Duration of the vacuum extraction, number of individual tractions and magnitude of the maximum tractive force clearly correspond with the level of the fetal head.

In 22 cases the maximum tractive force was $\geqq 20 \mathrm{kp}$. With a force of less than $20 \mathrm{kp}$ no coming off of the suction cup was observed.

The force-time-integral (FTI) of each record was evaluated
1. The FTI during the vacuum extraction clearly corresponds with the size of fetus and the level of the fetal head.

5. Severe depression which cannot be explained by acidosis and/or hypoxia is more often found after vacuum extractions with a great FTI.

3. Coming off of the suction cup was noted in our studies at a tractive force of more than $20 \mathrm{kp}$. planimetrically; it presents the time integral of force. In more than $80 \%$ of the cases vacuum extraction was indicated by delay of second stage or acidity-increase in the fetus. The FTI increases in correspondence to the level of the fetal head. Tractions with FTI-values of less than $375 \mathrm{kpsec}$ were required chiefly for extractions from the pelvic outlet (Fig. 2). Tractions of more than $1500 \mathrm{kpsec}$ were necessary only for extractions from higher pelvic levels. As the FTI increases, the relative portions of vacuum extractions from higher levels correspond almost inversely proportional to those from lower levels. The FTI correlates to birthweight as well. The level of the fetal head and the birthweight are therefore the two most important parameters for the FTI of a vacuum extraction.

The risk of depression grows with an increasing FTI; 11 of the 74 newborns delivered by vacuum extraction were depressed.

We have arbitrarily divided the degree of severity of a vacuum extraction into three groups:

1. Easy vacuum extraction up to $375 \mathrm{kpsec}$

2. Mildly difficult vacuum extraction $376-1125 \mathrm{kpsec}$

3. Difficult vacuum extraction 1126 and more kpsec.

It remains to be resolved whether the neonatal depression can be explained as a result of the vacuum extraction or other causes.

The blood pH-measurements of the umbilical artery enabled us to exclude a hypoxia as a cause of depression in at least 4 of the total 11 cases. A connection between vacuum extraction and neonatal depression can be suspected.

We judge this method to be an important step toward a complete collection of data concerning the birth. Subjective miscalculations can thus be eliminated in the future.

Keywords: Fetus, tractive force, vacuum extraction. 


\section{Zusammenfassung}

Analyse der Zugkräfte bei der Vakuumextraktion

Anhand der von uns entwickelten Vakuumextraktionszugmeßausrüstung [4] (Abb. 1) wurden 74 klinisch indizierte Vakuumextraktionen überwacht und nach folgenden Parametern ausgewertet:

Dauer des gesamten operativen Eingriffs

Gesamtdauer der applizierten Züge

Größe der maximalen Zugkraft

Anzahl der Einzelzüge

Kraft-Zeit-Integral (KZI).

Für Extraktionen aus den verschiedenen Beckenebenen ließen sich folgende Mittelwerte errechnen (Becken-Eingang $=\mathrm{BE}$, Becken-Mitte $=\mathrm{BM}$, Becken-Boden $=\mathrm{BB}$, Becken-Ausgang = BA):

Zahl der Züge: BE: 2,5; BM: 2,52; BB:1,95; BA: 1,66. Maximale Zugkraft: $\mathrm{BE}: 19,50 \mathrm{kp} ; \mathrm{BM}: 17,84 \mathrm{kp}$; BB: $14,31 \mathrm{kp}$; BA: 10,33 kp.

Dauer des operativen Eingriffes: $B E$ : $3 \mathrm{~min}$; $B M$ : $2 \mathrm{~min}, 34 \mathrm{sec}$; BB: $1 \mathrm{~min}, 19 \mathrm{sec}$; BA: $1 \mathrm{~min}, 10 \mathrm{sec}$.

Gesamtdauer der applizierten Züge: $\mathrm{BE}: 2 \mathrm{~min}, 37 \mathrm{sec}$; $\mathrm{BM}$ : $2 \mathrm{~min}, 10 \mathrm{sec}$; $\mathrm{BB}: 1 \mathrm{~min}, 17 \mathrm{sec}$; $\mathrm{BA}: 1 \mathrm{~min}, 2 \mathrm{sec}$.

Alle untersuchten Fälle waren Schädellagen, 44 Kinder wurden aus Beckenmitte, 22 vom Beckenboden, 6 aus Beckenausgang, 2 aus Beckeneingang entwickelt.

Dauer der Vakuumextraktion, Anzahl der Einzelzüge und Größe der maximalen Zugkraft korrelieren deutlich mit dem Höhenstand des kindlichen Kopfes.

$22 \mathrm{mal}$ betrug die maximale Zugkraft $\geqq 20 \mathrm{kp}$. Unterhalb einer Zugkraft von $20 \mathrm{kp}$ war kein Abreißen der Saugglocke zu beobachten. Das Kraft-Zeit-Integral (KZI) eines jeden Zugmeßprotokolls wurde planimetrisch bestimmt; es repräsentiert das Zeitintegral der Kraft. In mehr als $80 \%$ der Fälle erfolgte die VE wegen Geburtsstillstandes oder einer durch Fetalblutanalysen festgestellten

Schlüsselwörter: Fetus, Vakuumextraktion, Zugkräfte.
Aziditätssteigerung beim Féten. Das KZI wächst in Abhängigkeit vom Höhenstand des kindlichen Kopfes. Züge mit KZI-Werten unter $375 \mathrm{kpsec}$ wurden vorwiegend zur Extraktion aus Beckenboden und Beckenausgang benötigt (Abb. 2). Züge mit mehr als $1500 \mathrm{kpsec}$ waren nur für Extraktionen aus höheren Beckenebenen erforderlich. Mit steigendem KZI verhalten sịch die relativen Anteile von Vakuumextraktionen aus höheren Ebenen im Vergleich zu denen aus niederen Ebenen nahezu umgekehrt proportional (Abb. 3). Das KZI korreliert auch mit dem kindlichen Geburtsgewicht. Der Höhenstand des kindlichen Kopfes und das Geburtsgewicht sind somit die beiden wesentlichen Parameter für das KZI einer Vakuumextraktion.

Das Risiko eines Depressionszustandes nimmit mit steigendem KZZI zu (Abb. 4); 11 der 74 dụrch VE entwickelten Kinder wurden in einem Depressionszustand geboren.

Zur Differenzierung des Schweregrades einer Vakuumextraktion haben wir zunächst willkürlich die VE in drei Gruppen unterteilt:

\section{Leichte VE bis $375 \mathrm{kpsec}$}

2. Mittelschwere VE $376-1125 \mathrm{kpsec}$

3. Schwere VE $1126 \mathrm{kpsec}$ und mehr.

Es bleibt zu klären, ob der kindliche Depressionszustand als Folge der VE anzusehen oder vielmehr durch andere Ursachen erklärbar ist. Durch die Meßergebnisse der Nabelarterienblut-pH-Werte unmittelbar post partum konnte in mindestens 4 der insgesamt 11 Fälle mit Depressionszustand eine Hypoxie als Ursache der Depression ausgeschlossen werden, so daß an Beziehungen zwischen der VE und dem kindlichen Depressionszustand gedacht werden muß. Wir halten das Zügmeßprotokoll für einen weiteren wichtigen Schritt zur Vervollständigung wichtiger, das Kind betreffender Geburtsdaten. Subjektive Fehl einschätzungen werden hiermit in Zukunft vermieden.
Résumé

Analyses des forces de traction durant l'application de l'extraction obstétricale

A l'aide des instruments de mesure que nous avons mis au point [4] (Fig.1), nous avons observé 74 extractions obstétricales sur indication clinique en déterminant les paramètres suivants:

Durée de toute l'intervention opératoire Durée totale des tractions appliquées Grandeur de la force de traction maximale Nombre des tractions individuelles Intégrale force-temps (IFT).
Pour les extractions des divers détroits du bassin, on a trouvé les valeurs moyennes suivantes (détroit supérieur du bassin = PI, détroit moyen du bassin = MP, plancher pelvien $=\mathrm{PF}$, détroit inférieur du bassin $=\mathrm{PO}$ ):

Nombre des tractions: PI: 2,5; MP: 2,52; PF: 1,95; PO: 1,66 .

Force de traction maximale: PI: $19,50 \mathrm{kp} ; \mathrm{MP}: 17,84 \mathrm{kp}$; PF: 14,31 kp; PO: 10,33 kp.

Durée de l'intervention opératoire: PI: $3 \mathrm{~min}$; MP: $2 \mathrm{~min}, 34 \mathrm{sec}$; PF: $1 \mathrm{~min}, 19 \mathrm{sec}$; PO: $1 \mathrm{~min}, 10 \mathrm{sec}$. 
Duréc totale des tractions appliquées: $\mathrm{PI}: 2 \mathrm{~min}$, $37 \mathrm{sec}$; MP: $2 \mathrm{~min}, 10 \mathrm{sec}$; PF: $1 \mathrm{~min}, 17 \mathrm{sec}$; PO: $1 \mathrm{~min}$, $2 \mathrm{sec}$.

Tous les cas obscrvés présentaient une position du sommet. 44 nouveaux-nés ont été délivrés du détroit moyen du bassin, 22 du plancher pelvin, 6 du détroit inférieur du bassin et 2 du détroit supćrieur du bassin.

La durée de l'extraction obstétricale, le nombre des tractions individuclles et la grandeur de la force de traction maximale dépendent clairement du niveau de la tête du foetus.

Dans $22 \mathrm{cas}$, la force de traction maximale ćtait $\geqq 20 \mathrm{kp}$. Pour une force de traction inférieure a $20 \mathrm{kp}$, on n'a observé aucun détachement de la ventouse. L'intégrale force-temps (IFT) de chaque cas enregistré a été mesurće planimètriquement; elle représente l'intégrale temps de la force. Dans plus de $80 \%$ des cas, on a dû recourir à l'extraction obstétricale à cause d'un retard de la deuxième période d'accouchement ou d'une augmentation d'acidité chez le foctus. L'IFT augmente proportionnellement au niveau de la têtc du foctus. Les tractions de valeurs IFT inférieures à $375 \mathrm{kpsec}$ furent nécessitécs surtout pour les extractions du détroit inférieur du bassin et du plancher pelvien (Fig. 2) et les tractions supéricures d $1500 \mathrm{kpsec}$ seulement pour les extractions des détroits supćricurs du bassin. Pour une IF'T croissante, les portions relatives des extractions des détroits supćricurs sont prescu'inversement proportionnelles à celles des détroits inférieurs (Fig.3). L'IFT correspond aussi au poids du nouveau-né. Le niveau de la tête du foetus et le poids du nouvcau-né constituent, en conséquence, les deux paramètres essenticls pour l'IFT d'une extraction obstćtricalc.

Le risque d'un état dépressif augmente avec une IFT croissante (Fig. 4); il atteignit 11 des 74 nouvcaux-nćs délivrés par extraction. Nous avons fixć arbitrairement le degré de gravité d'une extraction selon les trois groupes suivants:

1. Extraction facile jusqu'd $375 \mathrm{kpsec}$

2. Extraction semi-difficile de $376-1125 \mathrm{kpscc}$

3. Extraction difficile de $1126 \mathrm{kpsec}$ et plus.

Il reste à détermincr si l'ćtat dépressif néonatal résulte de l'extraction obstétricale ou d'autres causes. Les mesurcs du pH du sang artériel ombilical effectućes aussitôt post partum ont permis d'exclure chez au moins 4 des 11 cas de dépression l'hypoxémie comme cause de cet état dépressif, ce qui amène d̀ suspecter une corrélation entre l'extraction obstétricale ct l'ćtat dépressif nćonatal.

Nous estimons que cette méthode représente un progrès important pour compléter les donnćes relatives à la naissance ct éviter dans l'avenir des crreurs d'apprćciation subjectives.

Mots-clés: Fetus, force de traction, ventouse.

Acknowledgement: This investigation was supported by grants from the Deutsche Forschungsgemeinschaft.

\section{Bibliography}

[1] Chalmers, J. A.: The Ventouse, the Obstetric Vacuum Extractor. Lloyd-Luke Ltd., London 1971

[2] Malmström, T.: Vacuum-Extractor - an Obstetric Instrument. Acta obstet. gyncc. scand. 33, Suppl. 4 4 (1954)

[3] Saling, E., K. H. Wulf: Zustandsdiagnostik beim
Neugeborenen - Gruppeneinteilung. Fortschr. Med. 89 (1971) 12

[4] Saling, E., U. Brücher, H. SANDER: Equipment for the recording of tractive power in vacuum extractions J. Perinat. Med. 1 (1973) 142
Prof. Dr. E. Saling

Unit of Pcrinatal Medicine

Mariendorfer Wcg 28-38

D-1000 Berlin 44/Germany

Note: The completc equipment is manufactured and distributed by KNICK, Katharinenstraßc 2, D-1000 Berlin 37 (WcstBerlin). 